\title{
Novel mutation in HTRA1 in a family with diffuse white matter lesions and inflammatory features
}

Amin Ziaei, MD, * Xiaohong Xu, MD, PhD, * Leila Dehghani, MSc, Carine Bonnard, PhD, Andreas Zellner, PhD, Alvin Yu Jin Ng, PhD, Sumanty Tohari, BSc, Byrappa Venkatesh, PhD, Christof Haffner, PhD,

Bruno Reversade, PhD, Vahid Shaygannejad, MD, and Mahmoud A. Pouladi, PhD

Neurol Genet 2019;5:e345. doi:10.1212/NXG.0000000000000345

\section{Abstract \\ Objective}

To investigate the possible involvement of germline mutations in a neurologic condition involving diffuse white matter lesions.

\section{Methods}

The patients were 3 siblings born to healthy parents. We performed homozygosity mapping, whole-exome sequencing, site-directed mutagenesis, and immunoblotting.

\section{Results}

All 3 patients showed clinical manifestations of ataxia, behavioral and mood changes, premature hair loss, memory loss, and lower back pain. In addition, they presented with inflammatory-like features and recurrent rhinitis. MRI showed abnormal diffuse demyelination lesions in the brain and myelitis in the spinal cord. We identified an insertion in high-temperature requirement $\mathrm{A}$ (HTRA1), which showed complete segregation in the pedigree. Functional analysis showed the mutation to affect stability and secretion of truncated protein.

\section{Conclusions}

The patients' clinical manifestations are consistent with cerebral autosomal recessive arteriopathy with subcortical infarcts and leukoencephalopathy (CARASIL; OMIM \#600142), which is known to be caused by HTRA1 mutations. Because some aspects of the clinical presentation deviate from those reported for CARASIL, our study expands the spectrum of clinical consequences of loss-of-function mutations in HTRA1.

\author{
Correspondence \\ Dr. Pouladi \\ map@pouladilab.org
}




\section{Glossary}

AMD = age-related macular degeneration; CARASIL = cerebral autosomal recessive arteriopathy with subcortical infarcts and leukoencephalopathy; $\mathbf{c H T Z}=$ compound heterozygous; $\mathbf{E C M}=$ extracellular matrix; HEK = human embryonic kidney; HMZ = homozygous; HTRA = high-temperature requirement A; IBD = identity by descent; MAF = minor allele frequency; SNP = single nucleotide polymorphism; TMAP = Torrent Mapping Alignment Program; $\mathbf{W T}=$ wild type.

The high-temperature requirement A (HTRA) family of proteins are serine proteases, which were initially identified in Escherichia coli as heat shock proteins and appear to play an important role in protein quality control. ${ }^{1}$ Four mammalian HTRA proteins, HTRA1-4, have been identified to date, and all contain a highly conserved trypsin-like protease domain. ${ }^{2}$ Human HTRA1 is located on chromosome $10 \mathrm{q} 26$ and was identified originally as being repressed in SV40transformed fibroblasts. ${ }^{3}$ The majority of this ubiquitously expressed enzyme is secreted into the extracellular space, with only approximately a fifth remaining in the cytoplasm where it can associate with microtubules. ${ }^{4}$ Almost all identified substrates of HTRA1 such as collagen II, clusterin, fibronectin, biglycan, fibromodulin, vitronectin, decorin, aggrecan, ${ }^{5}$ and latent transforming growth factor beta binding protein $1^{6}$ are extracellular matrix (ECM) proteins, suggesting a critical role for HTRA1 in ECM homeostasis. ${ }^{6}$

Altered expression or activity of HTRA1 has been linked to a number of diseases including age-related macular degeneration, ${ }^{7}$ cancer, ${ }^{4,8,9}$ and Alzheimer disease. ${ }^{10}$ More recently, inactivating mutations in HTRAl have been shown to cause cerebral autosomal recessive arteriopathy with subcortical infarcts and leukoencephalopathy (CARASIL; OMIM \#600142), ${ }^{11}$ a hereditary white matter disease characterized by subcortical infarcts with nonhypertensive cerebral small vessel arteriopathy, spondylosis, and alopecia, and typically manifesting in the third decade of life. ${ }^{12-14}$ Here, we report the discovery and functional characterization of a novel mutation in HTRA1 in 3 siblings with neurologic symptoms and diffuse white matter lesions consistent with CARASIL and some atypical features such as spinal cord myelitis and rhinitis only in affected members.

\section{Methods}

\section{Research study participants}

Board-certified clinical neurologist evaluated family members (IV.1, IV.2, and V.1-V.6) clinically. Clinical evaluation involved history taking, including family history, physical examination, and neurologic examination. We enrolled 6 siblings from 1 consanguineous family. We isolated genomic DNA from 8 members from this family: 3 probands, 3 unaffected siblings, and 2 parents. There are 2 additional affected individuals (V.7 and IV.5) in this pedigree who were not assessed genetically because of the lack of access to their blood samples.

\section{Standard protocol approvals, registrations, and patient consents}

The entire family was recruited under an Isfahan University of Medical Sciences ethics-approved research protocol with informed consent.

\section{Whole-exome sequencing}

Genomic DNA from proband V.2 was collected and used for whole-exome sequencing. DNA was extracted using a QIAamp DNA extraction kit (Qiagen). Using the Ion TargetSeq Exome and Custom Enrichment Kit (Thermo Fisher), $1 \mu \mathrm{g}$ of gDNA was processed and captured according to the manufacturer's instructions. Captured DNA molecules were sequenced on an Ion Proton instrument (Thermo Fisher) using the ION PI Chip Kit (Thermo Fisher). Sequence reads were aligned to the GRCh37 human reference genome assembly by the Torrent Mapping Alignment Program, which is a sequence alignment software program optimized especially for Ion Torrent data. A coverage of $82.14 \%$ was achieved across the exome, with $97.45 \%$ of the targeted sequences covered at $\geq$ $20 x$. The variants were then called using the Torrent Variant Caller plugin from the Torrent Suite (v4.2.1) and were then annotated using the "annotate single sample variants" workflow. The annotation items for the called variants included the associated gene name, variant location, quality score, coverage, predicted functional consequences, protein position and amino acid changes, scale invariant feature transform (SIFT), PolyPhen2, Mendelian Clinically Applicable Pathogenicity (M-CAP) and Grantham prediction scores, PhyloP conservation scores, and 5000 genomes Minor Allele Frequencies. To exclude common single nucleotide polymorphisms (SNPs), the annotated variants were filtered using the ClinVar database (ftp://ftp.ncbi.nlm.nih.gov/pub/clinvar/vcf_GRCh37/)

Table 1 Summary of homozygous loci $(>2 \mathrm{~cm})$ shared between affected probands (V.2, V.3, and V.4) and not present in healthy family members (IV.1, IV.2, V.1, V.5, and V.6)

\begin{tabular}{llll}
\hline Chr. & Start & End & Length \\
\hline $\mathbf{1}$ & $108,247,048$ & $120,434,626$ & $12,187,578$ \\
\hline $\mathbf{1}$ & $145,587,476$ & $157,497,406$ & $11,909,930$ \\
\hline $\mathbf{7}$ & $36,530,276$ & $44,243,953$ & $7,713,677$ \\
\hline $\mathbf{1 0}$ & $121,950,989$ & $128,473,047$ & $6,522,058$ \\
\hline
\end{tabular}


Figure 1 Family pedigree, clinical features, and results of the genetic assessment
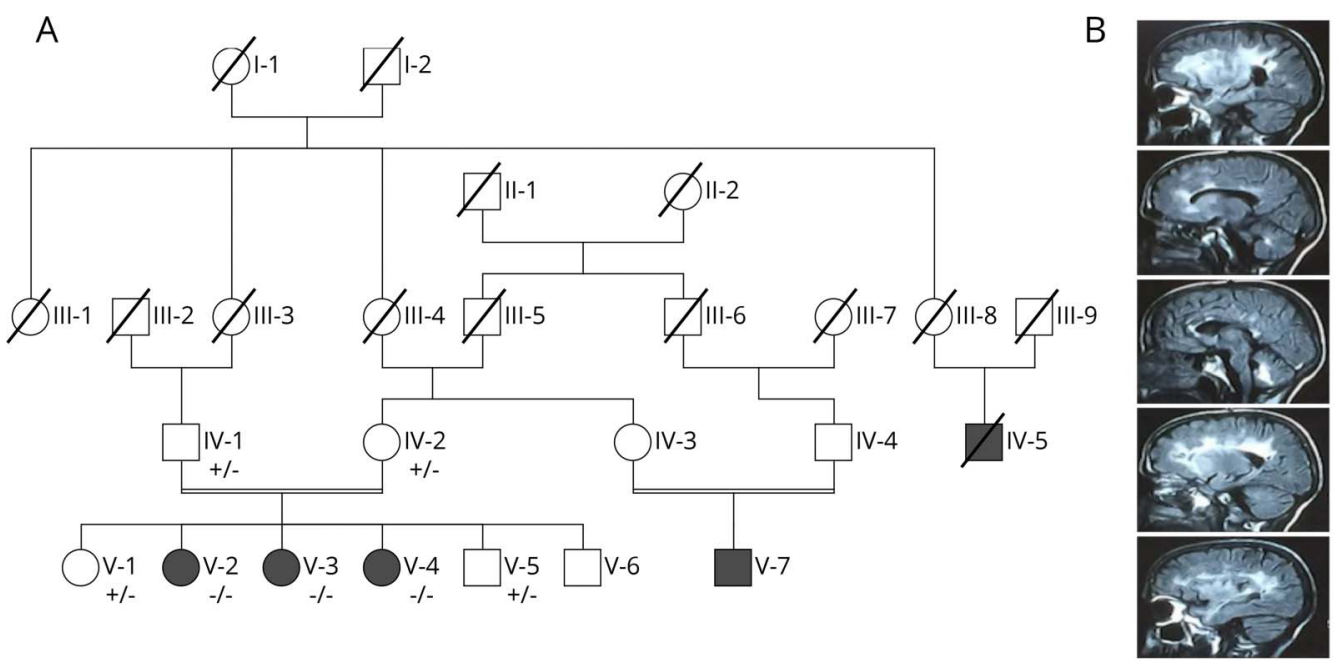

C

SNVS and INDELS
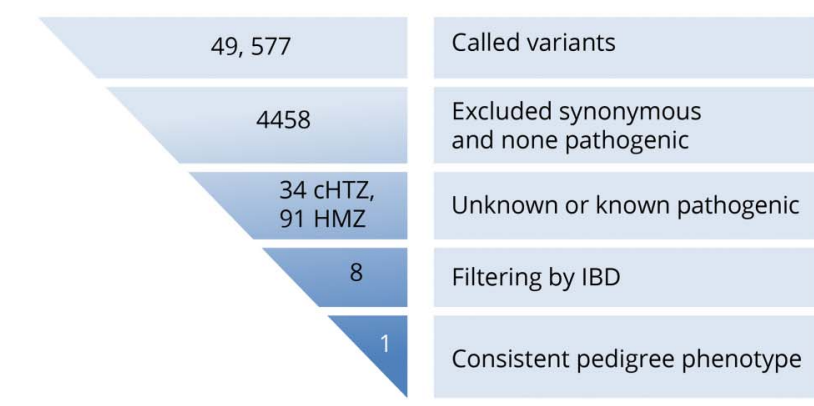

D

E

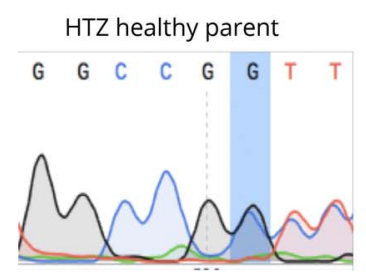

HMZ-affected member

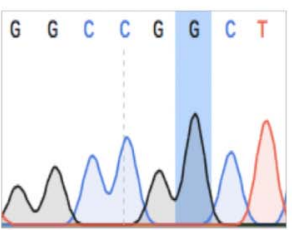

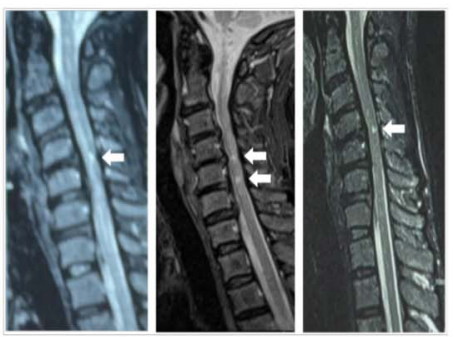

F

HTRA1: C.805insG [HTRA1 ${ }^{5270 L \mathrm{Ls}^{*} 69}$ ]

Normal GGC CGC TCC TCA GAG Gly Arg Ser Ser Glu

Frameshift GGC CGg CTC CTC AGA Gly Arg Leu Leu Arg

(A) Family pedigree showing the affected patients as dark gray-filled symbols. (+) refers to wild-type allele; (-) refers to mutant allele. (B) Filtering procedure of whole-exome variants. (C) MRIs of the affected proband (V.2) with multiple frontal and parietal white matter hyperintensities on T2w flair MRI, suggestive of diffuse demyelination lesion. (D) Representative spinal cord MRIs of affected probands (left: V.2, center: V.3, and right: V.4). White arrows indicating that hyperintensity signal lesions are suggestive of myelitis. (E) Confirmation of mutation in HTRA1 and its segregation by Sanger sequencing. (F) Predicted effect of the HTRA1S270Lfs*69 identified mutation on protein sequence. $\mathrm{HMZ}=$ homozygous; $\mathrm{HTRA}=$ high-temperature requirement $\mathrm{A}$; $\mathrm{HTZ}=$ heterozygous; IBD = identity by descent; INDELs = insertions or deletions; SNVs = single nucleotide variants.

and the Exome Aggregate Consortium data set (ftp://ftp. broadinstitute.org/pub/ExAC release/release $0.2 /)$ Variants were next compared with an in-house database containing 485 previously sequenced samples, which largely represent participants from the Middle East including Iran, and those that were present in more than $1 \%$ of the previously sequenced samples were removed.

\section{Identity-by-descent mapping}

All blood samples were genotyped using Illumina HumanOmni $2.5-4 \mathrm{v} 1 \mathrm{H}$ SNP array according to the manufacturer's instructions. Genotypes were called using
Illumina GenomeStudio software with call rates $>99 \%$, and then, sex and parents-offspring family relationship were further verified. Identity-by-descent (IBD) mapping was performed by searching for shared homozygous (HMZ) regions among the 3 affected patients using customized programs written in Mathematica (Wolfram Research, Inc.). All HMZ regions that were $>2 \mathrm{~cm}$ were examined allowing $1 \%$ error rate. Those candidate regions were further refined by exclusion of HMZ segments present in a parents and unaffected members. The identified shared HMZ loci are summarized in table 1. 
Table 2 Summary of signs and symptoms in the affected siblings

\begin{tabular}{|c|c|c|c|}
\hline Participant & V.2 & V.3 & V.4 \\
\hline Age at diagnosis (y) & 34 & 30 & 32 \\
\hline Leg involvement (spasticity) & +++ & ++ & ++ \\
\hline Gait problem (ataxia) & +++ & ++ & ++ \\
\hline Behavioral and mood changes (aggression) & ++ & +++ & +++ \\
\hline Dysarthria & ++ & - & - \\
\hline Memory loss & ++ & + & + \\
\hline Premature hair loss & ++ & + & + \\
\hline Low back pain & ++ & + & + \\
\hline Spinal canal stenosis & + & + & + \\
\hline Recurrent rhinitis & ++ & + & + \\
\hline
\end{tabular}

\section{Cloning of HTRA1S270L ${ }^{\text {fs*69 }}$ HTRA $1^{\text {S270Lfs*69 }}$ plasmid}

The wild-type (WT) HTRA1 plasmid, which contains coding DNA sequence of the HTRA1 gene in pcDNA3.1 vector, is a gift from Professors Hiroaki Nozaki and Osamu Onodera (Brain Research Institute, Niigata University, Niigata, Japan). To introduce a "G" into CDNA of HTRA1 at position 805 base pair for construction of HTRA1 ${ }^{\text {S270Lfs*69 }}$ plasmid, we used site-directed mutagenesis by the PCR method. In brief, the whole HTRA1 plasmid template was amplified using the primers of forward $5^{\prime}$ -GCCTGTCCTGCTGCTTGGCCGGCTCCTCAGAGCTGCGGCCGGG-3' and reverse 5' CCCGGCCGCAGCTCTGAGGAGCCGGCCAAGCAGCAGGACAGGC-3' with KOD Xtreme Hot Start DNA Polymerase (Novagen, \#71975), and cycling conditions were as follows: initial denaturation at $95^{\circ} \mathrm{C}$ for 4 minutes, followed by 15 cycles of $95^{\circ} \mathrm{C}$ for 30 seconds, $50^{\circ} \mathrm{C}$ for 1 minute, and $68^{\circ} \mathrm{C}$ for 7 minutes; The PCR product was purified and incubated

Table 3 Features of the novel HTRA1 mutation identified

\begin{tabular}{ll}
\hline Feature & 10 \\
\hline Chromosome number & 124266234 \\
\hline Position of mutation & 0 \\
\hline $\begin{array}{l}\text { Minor allele frequency (ExAC, UK10, in-house } \\
\text { database of 485 exomes) }\end{array}$ & HTRA1 \\
\hline Gene name & Exonic \\
\hline Nature of mutation & 4 \\
\hline Exon no. & p.Ser270Leufs $* 69$ \\
\hline Change introduced in protein product & 2.46 \\
\hline PhyloP score &
\end{tabular}

HTRA = high-temperature requirement $\mathrm{A}$. with Dpn1 (a methylation-dependent endonuclease) for 2 hours at $37^{\circ} \mathrm{C}$. The digested PCR product was transformed into $E$. coli DH5a and was then plated on lysogeny broth agar plate with $100 \mu \mathrm{g} / \mathrm{mL}$ ampicillin. Eight colonies were picked from the LB agar plate and sent to Axil Scientific Pte Ltd for sequencing. One of the positive colonies confirmed by sequencing was purified for transfection using the EndoFree Plasmid Maxi Kit (Qiagen, \#12362).

\section{Cell culture, transfection, and Western blot analysis}

Human embryonic kidney cells (HEK293, ATCC CRL-1573) were grown in high-glucose Dulbecco's Modified Eagle Medium, supplemented with Glutamax, sodium pyruvate, and $10 \%$ fetal bovine serum (Gibco, Thermo Fisher Scientific) at $37^{\circ} \mathrm{C}$ and $5 \%$ $\mathrm{CO}_{2}$. Transient transfection was performed using Lipofectamine 2000 according to the manufacturer's instructions (Thermo Fisher Scientific). Serum-free conditioned media were collected 24 hours after transfection and cleared by centrifugation at $1,000 \mathrm{~g}$ for 5 minutes. Cells were lysed in a buffer containing $25 \mathrm{mM}$ Tris$\mathrm{HCl} \mathrm{pH}$ 7.6, $150 \mathrm{mM} \mathrm{NaCl}, 1 \%$ sodium deoxycholate, $0.1 \%$ sodium dodecyl sulfate, and 1\% Nonidet P-40. Lysates and conditioned cell culture supernatants were analyzed by sodium dodecyl sulfate-polyacrylamide gel electrophoresis and electrotransfer onto $0.2 \mu \mathrm{m}$ nitrocellulose membranes using the MiniProtean and Trans-Blot system (Biorad). Membranes were blocked with Tris-buffered saline supplemented with $0.1 \%$ Tween 20 and $4 \%$ nonfat milk for 1 hour at room temperature and probed overnight at $4{ }^{\circ} \mathrm{C}$ using rabbit polyclonal anti-HTRA1 (HPA036655, Sigma-Aldrich, 1: 5,000) and rabbit polyclonal anti-GAPDH (AB9485, Abcam, 1: 2,500) antibodies. Detection was performed with horseradish peroxidase-conjugated secondary antibodies (Cell Signaling, 1: 10,000), chemiluminescence development (Immobilon ECL detection reagent, Merck Millipore), and the Fusion FX7 imaging system (Vilber Lourmat).

\section{Data availability}

All anonymized data can be shared on a collaborative basis.

\section{Results}

In this study, 3 affected sibling patients and their unaffected parents from 1 consanguineous pedigree in Isfahan province, Iran, were analyzed. In all affected probands (figure 1A: V.2, V.3, and V.4), the manifestations appeared at almost the same age at onset at the beginning of their third decade of life. These 3 patients all developed clinical features such as gait problems, aggressive behavioral and mood changes, memory loss, premature hair loss, low back pain, and spinal canal stenosis. Furthermore, only the affected members presented with recurrent rhinitis that is chronic and nonseasonal, appearing monthly with allergic-like symptoms such as sneezing. Moreover, the disease features in the elder proband V.2 were more prominent than those in younger patients V.3 and V.4. These signs and symptoms have persisted and are summarized in table 2 . MRI was only performed on the 3 affected siblings based on their neurologic presentation and showed abnormal diffuse demyelination lesions 


\section{Figure $2 H_{T R A} 1^{\text {S270Lfs*69 }}$ is poorly expressed and in- efficiently secreted}

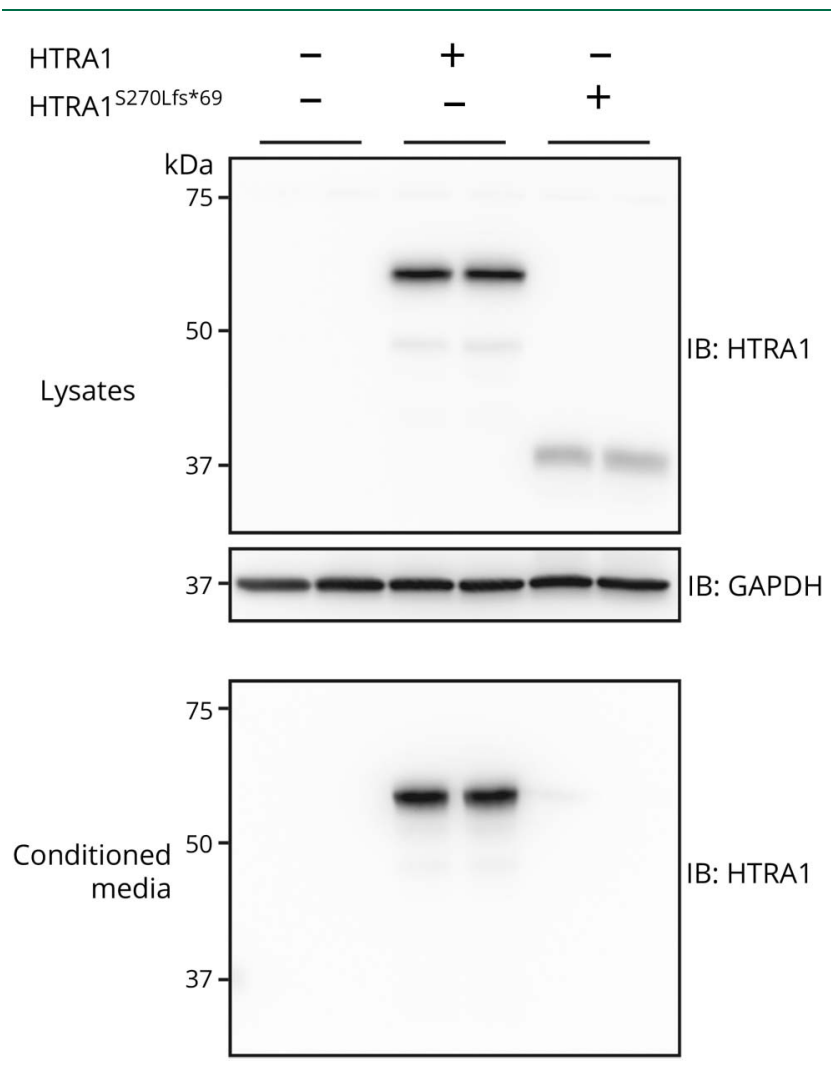

Immunoblots of cell lysates and conditioned media from HEK293 cells transiently transfected with plasmids encoding wild-type HTRA1 or the truncated variant HTRA $1^{\text {S270Lfs }} 69$. The migration behavior of HTRA $1^{\text {S270Lfs* } 69}$ is in agreement with its predicted molecular weight $(\sim 37 \mathrm{kDa})$. For the detection of HTRA1, a polyclonal antibody against amino acids 120-179 of HTRA1 was used (Sigma-Aldrich). Equal volumes of conditioned media were analyzed; for the cell lysates, GAPDH (glyceraldehyde 3-phosphate dehydrogenase) was used as a loading control. HTRA = high-temperature requirement $A$.

in the brain (figure 1B), spondylotic changes of the lumbar spine, and spinal channel stenosis (data not shown). In addition, only the affected siblings showed lower limb weakness, which was responsive to corticosteroid (methylprednisolone) treatment and hyperintensity signals on T2-weighted MRIs suggestive of myelitis in the spinal cord (figure 1C).
To identify possible disease-related mutations, whole-exome sequencing was performed on the affected proband V.2. A total of 5,558 potentially pathogenic variants were identified across protein-coding exons, untranslated regions, splice sites, and flanking introns. After following an autosomal recessive model of inheritance, a final set of $91 \mathrm{HMZ}$ variants and 75 compound heterozygous (cHTZ) variants (34 gene sets) was identified (figure 1D). Of those, 8 variants ( $3 \mathrm{cHTZ}$ variants in 1 gene and $5 \mathrm{HMZ}$ variants in 5 genes) were located in the loci determined by IBD mapping and shared among the 3 siblings. The CHTZ variants in the CROCC gene did not pass our filtering criteria because 2 of the 3 are intronic and not conserved. Similarly, 2 intronic and poorly conserved variants in MIR7851 and LINC01138 and 1 exonic nonconserved variant in TNRC18, predicted to be nondeleterious by SIFT and PolyPhen, were excluded. The 2 remaining shared variants were a frameshift mutation in HTRA1 and a missense mutation in CGN. The missense mutation in CGN has a minor allele frequency (MAF) higher than $1 \%$ in healthy subject databases, and the affected amino acid, Gly 415, is not conserved in humans. Furthermore, CGN-deficient mice have not been reported to exhibit any immunologic or neurologic abnormalities. ${ }^{15}$ Therefore, the clinical manifestations in our patients are not likely to be related to the missense mutation in CGN. The only remaining mutation consistent with the patients' phenotype that passed our filtering criteria including MAF below $1 \%$ in public and proprietary variant databases, exonic or highly conserved intronic variant (based on PhyloP score), and pathogenic score based on SIFT, PolyPhen, and $\mathrm{M}-\mathrm{CAP}^{16}$ was the HTRAI ${ }^{\text {S270Lfs*69 }}$ mutation (table 3 ). It was confirmed by Sanger sequencing and showed complete segregation in the pedigree (figure $1 \mathrm{E}$ ) as a " $\mathrm{G}$ " insertion mutation at position 805 (c.805_806insG) in HTRA1, which is predicted to result in a truncated HTRA1 protein p. Ser270Leufs 69 (figure 1F).

To examine the expression and secretion of the HTRA1 ${ }^{\mathrm{S} 270 \mathrm{Lf} \mathrm{fs}^{*} 69}$ variant, the WT and mutant HTRAl plasmids were transfected into HEK293 cells and conditioned medium and cell pellets were analyzed by Western blot 24 hours post-transfection (figure 2). The truncated protein was present at the predicted molecular

Figure 3 A schematic presentation of HTRA1 mutations

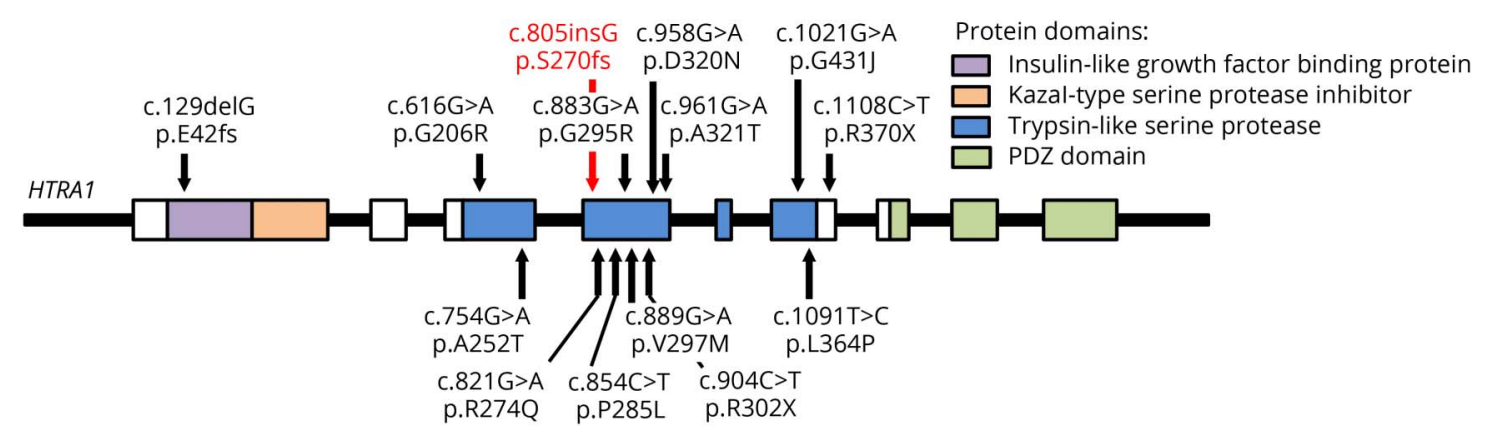

A representation of the HTRA1 gene, its protein domains, and the pathogenic mutations identified to date. The novel mutation reported here is highlighted in red. Scheme adapted from reference 28 . HTRA = high-temperature requirement $A$. 
weight in cell lysates, albeit at strongly reduced levels compared with full-length WT HTRA1. In conditioned supernatants, the mutant protein could not be detected at all, whereas WT HTRA1 was clearly identified (figure 2). These findings suggest that the S270Lfs*69 mutant might be rapidly degraded intracellularly preventing its secretion.

\section{Discussion}

Multiple HMZ mutations in HTRA1 have been found in patients with CARASIL. ${ }^{17-22}$ These mutations are concentrated in the protease domain, and all have been shown or are predicted to reduce the catalytic activity of HTRA1 (figure 3 ). In this study, we demonstrate that the novel HTRA1 variant we identified, which is located in the middle of the protease domain, results in a truncated protein lacking the active site serine residue $\left(S^{328}\right)$ and exhibiting significantly reduced expression levels.

Heterozygous HTRA1 mutations have been shown to be associated with a dominant, late-onset form of small vessel disease, without any extraneurologic symptoms. ${ }^{23,24}$ Although these mutations are mostly missense mutations, the mutation identified in the present study clearly results in a loss of HTRA1 function and thus represents a typical CARASIL mutation. Accordingly, the heterozygous parents of the 3 affected siblings were healthy despite an age well within the reported range of age at onset for the dominant small vessel disease form (IV.1: 58 years, IV.2: 68 years).

In this study, all 3 patients with the HTRA1 ${ }^{\text {S270Lfs*69 }}$ mutation demonstrated typical clinical CARASIL features and some atypical features such as recurrent rhinitis and possible spinal cord myelitis suggestive of inflammation with lower limb weakness responsive to corticosteroid (methylprednisolone) treatment. Of note, a case report recently described myelitis in cerebral autosomal dominant arteriopathy with subcortical infarcts and leukoencephalopathy. ${ }^{25}$ The presence of 2 additional affected participants (V.7 and IV.5) in this pedigree further supports the role of genetics in their clinical presentation. It is highly likely that these individuals carry the same HTRA1 mutation as the one harbored by the 3 analyzed participants in this study. Unfortunately, because DNA samples from these additional individuals are not available, it will not be possible to confirm this by genetic analysis.

The mechanism by which loss of HTRA1 function results in CARASIL has been proposed to involve altered TGF- $\beta$ signaling, although the exact nature of this dysregulation whether it is caused by excessive ${ }^{11,26-28}$ or reduced ${ }^{6}$ TGF- $\beta$ pathway activity remains a subject of debate. ${ }^{29}$ Moreover, TGF- $\beta$ has wellestablished immunoregulatory roles. ${ }^{30}$ We speculate that the inflammatory features of the probands in the present study such as spinal cord myelitis and recurrent rhinitis may be related to the dysregulation of TGF- $\beta$ signaling. ${ }^{11,28}$ On the other hand, these symptoms, which are atypical for CARASIL, may be caused by other genetic variants shared by the 3 affected siblings, a possibility we cannot formally rule out.
HTRA1 has recently been shown to be enriched in mature astrocytes in the brain. ${ }^{31}$ Given their well-established role in cerebrovascular and blood flow regulation, ${ }^{32}$ it is tempting to speculate whether astrocytes play a role in mediating the inflammatory features and the cerebral arteriopathy in CARASIL. Of note, recent studies investigating Alexander disease, a leukodystrophy caused by mutations in the astrocyte-enriched glial fibrillary acidic protein, provide evidence of increased immune activation, cytokine production, and inflammatory response. ${ }^{33-35}$ These studies suggest an important role for astrocytic dysfunction in cerebrovascular and demyelinating disorders.

We identified a novel frameshift mutation in the CARASILassociated gene HTRAl and characterized its functional consequences. Moreover, some aspects of the clinical presentation in affected patients described here deviate from those previously reported in CARASIL. Therefore, our study expands the spectrum of clinical consequences of mutations in HTRA1.

\section{Acknowledgment}

The authors thank Professors Hiroaki Nozaki and Osamu Onodera (Brain Research Institute, Niigata University, Niigata, Japan) for the HTRA1 vectors.

\section{Study funding}

This study was supported by the Agency for Science Technology and Research (SPF2012/005) to M.A.P. and the German Research Foundation (DFG, HA2448/6-1) to C.H.

\section{Disclosure}

Disclosures available: Neurology.org/NG.

\section{Publication history}

Received by Neurology: Genetics October 29, 2018. Accepted in final form May 28, 2019.

Appendix Authors

\begin{tabular}{|c|c|c|c|}
\hline Name & Affiliation & Role & Contribution \\
\hline Amin Ziaei, MD & $\begin{array}{l}\text { Translational } \\
\text { Laboratory in Genetic } \\
\text { Medicine (TLGM), } \\
\text { Agency for Science, } \\
\text { Technology and } \\
\text { Research (A*STAR), } \\
\text { 8A Biomedical Grove, } \\
\text { Immunos, Level 5, } \\
\text { 138648, Singapore } \\
\text { Department of } \\
\text { Medicine, National } \\
\text { University of } \\
\text { Singapore, 117597, } \\
\text { Singapore } \\
\text { Department of } \\
\text { Neurology, Isfahan } \\
\text { Neurosciences } \\
\text { Research Centre, } \\
\text { Faculty of Medicine, } \\
\text { Isfahan University of } \\
\text { Medical Sciences, } \\
\text { Isfahan, Iran }\end{array}$ & Author & $\begin{array}{l}\text { Role in identifying } \\
\text { family and clinical } \\
\text { data acquisition; } \\
\text { designed and } \\
\text { conceptualized the } \\
\text { study; analyzed the } \\
\text { data; role in genetic } \\
\text { data analysis; and } \\
\text { drafted and revised } \\
\text { the manuscript. }\end{array}$ \\
\hline
\end{tabular}


Appendix (continued)

\begin{tabular}{|c|c|c|c|}
\hline Name & Affiliation & Role & Contribution \\
\hline $\begin{array}{l}\text { Xiaohong Xu, } \\
\text { MD, PhD }\end{array}$ & $\begin{array}{l}\text { Translational } \\
\text { Laboratory in } \\
\text { Genetic Medicine } \\
\text { (TLGM), Agency for } \\
\text { Science, Technology } \\
\text { and Research } \\
\text { (A*STAR), 8A } \\
\text { Biomedical Grove, } \\
\text { Immunos, Level 5, } \\
\text { 138648, Singapore } \\
\text { Department of } \\
\text { Neurology and } \\
\text { Stroke Center, the } \\
\text { First Affiliated } \\
\text { Hospital, Jinan } \\
\text { University, 613 } \\
\text { Huangpu Avenue } \\
\text { West, Guangzhou, } \\
\text { Guangdong 510632, } \\
\text { China } \\
\text { Clinical Neuroscience } \\
\text { Institute of Jinan } \\
\text { University, 613 } \\
\text { Huangpu Avenue } \\
\text { West, Guangzhou, } \\
\text { Guangdong 510632, } \\
\text { China }\end{array}$ & Author & $\begin{array}{l}\text { Designed and } \\
\text { conceptualized the } \\
\text { study; analyzed the } \\
\text { data; and drafted } \\
\text { and revised the } \\
\text { manuscript. }\end{array}$ \\
\hline $\begin{array}{l}\text { Leila } \\
\text { Dehghani, MSc }\end{array}$ & $\begin{array}{l}\text { Department of } \\
\text { Tissue Engineering } \\
\text { and Regenerative } \\
\text { Medicine, School } \\
\text { of Advanced } \\
\text { Technologies in } \\
\text { Medicine, Shahid } \\
\text { Beheshti } \\
\text { University of } \\
\text { Medical Sciences, } \\
\text { Tehran, Iran }\end{array}$ & Author & $\begin{array}{l}\text { Role in identifying } \\
\text { family and clinical } \\
\text { data acquisition and } \\
\text { revised the } \\
\text { manuscript. }\end{array}$ \\
\hline $\begin{array}{l}\text { Carine } \\
\text { Bonnard, PhD }\end{array}$ & $\begin{array}{l}\text { Institute of } \\
\text { Medical Biology } \\
\text { (IMB), A*STAR, 8A } \\
\text { Biomedical } \\
\text { Grove, Immunos, } \\
\text { Level 5, 138648, } \\
\text { Singapore }\end{array}$ & Author & $\begin{array}{l}\text { Genetic data } \\
\text { analysis and revised } \\
\text { the manuscript. }\end{array}$ \\
\hline $\begin{array}{l}\text { Andreas } \\
\text { Zellner, PhD }\end{array}$ & $\begin{array}{l}\text { Institute for Stroke } \\
\text { and Dementia } \\
\text { Research, Klinikum } \\
\text { der Universität } \\
\text { München, Ludwig } \\
\text { Maximilians } \\
\text { University, Munich, } \\
\text { Germany }\end{array}$ & Author & $\begin{array}{l}\text { Biochemical } \\
\text { analysis; } \\
\text { interpreted data; } \\
\text { and revised the } \\
\text { manuscript. }\end{array}$ \\
\hline $\begin{array}{l}\text { Alvin Yu Jin Ng, } \\
\text { PhD }\end{array}$ & $\begin{array}{l}\text { Comparative } \\
\text { Genomics } \\
\text { Laboratory, } \\
\text { Institute of } \\
\text { Molecular and } \\
\text { Cell Biology, } \\
\text { A*STAR, Biopolis, } \\
\text { Singapore 138673, } \\
\text { Singapore }\end{array}$ & Author & $\begin{array}{l}\text { Genetic data } \\
\text { analysis; Revised } \\
\text { the manuscript. }\end{array}$ \\
\hline $\begin{array}{l}\text { Sumanty } \\
\text { Tohari, BSc }\end{array}$ & $\begin{array}{l}\text { Comparative } \\
\text { Genomics } \\
\text { Laboratory, } \\
\text { Institute of } \\
\text { Molecular and Cell } \\
\text { Biology, A*STAR, } \\
\text { Biopolis, Singapore } \\
\text { 138673, Singapore }\end{array}$ & Author & $\begin{array}{l}\text { Genetic data } \\
\text { analysis and revised } \\
\text { the manuscript. }\end{array}$ \\
\hline
\end{tabular}

Appendix (continued)

\begin{tabular}{|c|c|c|c|}
\hline Name & Affiliation & Role & Contribution \\
\hline $\begin{array}{l}\text { Byrappa } \\
\text { Venkatesh, } \\
\text { PhD }\end{array}$ & $\begin{array}{l}\text { Comparative } \\
\text { Genomics } \\
\text { Laboratory, } \\
\text { Institute of } \\
\text { Molecular and Cell } \\
\text { Biology, A*STAR, } \\
\text { Biopolis, Singapore } \\
\text { 138673, Singapore }\end{array}$ & Author & $\begin{array}{l}\text { Genetic data } \\
\text { analysis and revised } \\
\text { the manuscript. }\end{array}$ \\
\hline $\begin{array}{l}\text { Christof } \\
\text { Haffner, PhD }\end{array}$ & $\begin{array}{l}\text { Institute for Stroke } \\
\text { and Dementia } \\
\text { Research, Klinikum } \\
\text { der Universität } \\
\text { München, Ludwig } \\
\text { Maximilians } \\
\text { University, Munich, } \\
\text { Germany }\end{array}$ & Author & $\begin{array}{l}\text { Biochemical } \\
\text { analysis; } \\
\text { interpreted data; } \\
\text { and revised the } \\
\text { manuscript. }\end{array}$ \\
\hline $\begin{array}{l}\text { Bruno } \\
\text { Reversade, } \\
\text { PhD }\end{array}$ & $\begin{array}{l}\text { Institute of Medical } \\
\text { Biology (IMB), } \\
\text { A*STAR, 8A } \\
\text { Biomedical Grove, } \\
\text { Immunos, Level 5, } \\
\text { 138648, Singapore }\end{array}$ & Author & $\begin{array}{l}\text { Genetic data } \\
\text { analysis and revised } \\
\text { the manuscript. }\end{array}$ \\
\hline $\begin{array}{l}\text { Vahid } \\
\text { Shaygannejad, } \\
\text { MD }\end{array}$ & $\begin{array}{l}\text { Department of } \\
\text { Neurology, Isfahan } \\
\text { Neurosciences } \\
\text { Research Centre, } \\
\text { Faculty of Medicine, } \\
\text { Isfahan University } \\
\text { of Medical Sciences, } \\
\text { Isfahan, Iran }\end{array}$ & Author & $\begin{array}{l}\text { Role in identifying } \\
\text { family and clinical } \\
\text { data acquisition and } \\
\text { revised the } \\
\text { manuscript. }\end{array}$ \\
\hline $\begin{array}{l}\text { Mahmoud A. } \\
\text { Pouladi, PhD }\end{array}$ & $\begin{array}{l}\text { Translational } \\
\text { Laboratory in } \\
\text { Genetic Medicine } \\
\text { (TLGM), Agency for } \\
\text { Science, Technology } \\
\text { and Research } \\
\text { (A*STAR), 8A } \\
\text { Biomedical Grove, } \\
\text { Immunos, Level 5, } \\
\text { 138648, Singapore } \\
\text { Department of } \\
\text { Medicine, National } \\
\text { University of } \\
\text { Singapore, 117597, } \\
\text { Singapore } \\
\text { Department of } \\
\text { Physiology, National } \\
\text { University of } \\
\text { Singapore, 117597, } \\
\text { Singapore }\end{array}$ & Author & $\begin{array}{l}\text { Designed and } \\
\text { conceptualized the } \\
\text { study; analyzed the } \\
\text { data; role in genetic } \\
\text { data analysis; and } \\
\text { drafted and revised } \\
\text { the manuscript. }\end{array}$ \\
\hline
\end{tabular}

\section{References}

1. Clausen T, Southan C, Ehrmann M. The HtrA family of proteases. Mol Cell 2002;10: 443-455.

2. Clausen T, Kaiser M, Huber R, Ehrmann M. HTRA proteases: regulated proteolysis in protein quality control. Nat Rev Mol Cel Biol 2011;12:152-162.

3. Zumbrunn J, Trueb B. Primary structure of a putative serine protease specific for IGFbinding proteins. FEBS Lett 1996;398:187-192.

4. Chien J, Staub J, Hu SI, et al. A candidate tumor suppressor HtrAl is downregulated in ovarian cancer. Oncogene 2004;23:1636-1644.

5. An E, Sen S, Park SK, Gordish-Dressman H, Hathout Y. Identification of novel substrates for the serine protease HTRAl in the human RPE secretome. Invest Ophthalmol Vis Sci 2010;51:3379.

6. Beaufort N, Scharrer E, Kremmer E, et al. Cerebral small vessel disease-related protease HtrAl processes latent TGF- $\beta$ binding protein 1 and facilitates TGF- $\beta$ signaling. Proc Natl Acad Sci U S A 2014;111:16496-16501.

7. DeWan A, Liu M, Hartman S, et al. HTRA1 promoter polymorphism in wet agerelated macular degeneration. Science 2006;314:989-992. 
8. Baldi A, Luca AD, Morini M, et al. The HtrAl serine protease is down-regulated during human melanoma progression and represses growth of metastatic melanoma cells. Oncogene 2002;21:6684-6688.

9. Esposito V, Campioni M, De Luca A, et al. Analysis of HtrAl serine protease expression in human lung cancer. Anticancer Res 2006;26:3455-3459.

10. Grau S, Baldi A, Bussani R, et al. Implications of the serine protease HtrAl in amyloid precursor protein processing. Proc Natl Acad Sci U S A 2005;102:6021-6026.

11. Hara K, Shiga A, Fukutake T, et al. Association of HTRA1 mutations and familial ischemic cerebral small-vessel disease. N Engl J Med 2009;360:1729-1739.

12. Maeda S, Nakayama H, Isaka K, Aihara Y, Nemoto S. Familial unusual encephalopathy of Binswanger's type without hypertension. Psychiatry Clin Neurosci 1976;30:165-177.

13. Fukutake T, Hirayama K. Familial young-adult-onset arteriosclerotic leukoencephalopathy with alopecia and lumbago without arterial hypertension. Eur Neurol 1995;35:69-79.

14. Yanagawa S, Ito N, Arima K, Ikeda S. Cerebral autosomal recessive arteriopathy with subcortical infarcts and leukoencephalopathy. Neurology 2002;58:817-820.

15. Guillemot L, Schneider Y, Brun P, et al. Cingulin is dispensable for epithelial barrier function and tight junction structure, and plays a role in the control of claudin-2 expression and response to duodenal mucosa injury. J Cell Sci 2012;125:5005-5014.

16. Jagadeesh KA, Wenger AM, Berger MJ, et al. M-CAP eliminates a majority of variants of uncertain significance in clinical exomes at high sensitivity. Nat Genet 2016;48:1581-1586.

17. Bayrakli F, Balaban H, Gurelik M, Hizmetli S, Topaktas S. Mutation in the HTRA1 gene in a patient with degenerated spine as a component of CARASIL syndrome. Turk Neurosurg 2014;24:67-69.

18. Bianchi S, Di Palma C, Gallus GN, et al. Two novel HTRA1 mutations in a European CARASIL patient. Neurology 2014;82:898-900.

19. Chen Y, He Z, Meng S, Li L, Yang H, Zhang X. A novel mutation of the hightemperature requirement A serine peptidase 1 (HTRA1) gene in a Chinese family with cerebral autosomal recessive arteriopathy with subcortical infarcts and leukoencephalopathy (CARASIL). J Int Med Res 2013;41:1445-1455.

20. Mendioroz M, Fernandez-Cadenas I, del Rio-Espinola A, et al. A missense HTRA1 mutation expands CARASIL syndrome to the Caucasian population. Neurology 2010;75:2033-2035.

21. Nishimoto Y, Shibata M, Nihonmatsu M, et al. A novel mutation in the HTRA1 gene causes CARASIL without alopecia. Neurology 2011;76:1353-1355.
22. Wang XL, Li CF, Guo HW, Cao BZ. A novel mutation in the HTRA1 gene identified in Chinese CARASIL pedigree. CNS Neurosci Ther 2012;18:867-869.

23. Verdura E, Hervé D, Scharrer E, et al. Heterozygous HTRA1 mutations are associated with autosomal dominant cerebral small vessel disease. Brain 2015;138:2347-2358.

24. Nozaki H, Kato T, Nihonmatsu M, et al. Distinct molecular mechanisms of HTRA1 mutants in manifesting heterozygotes with CARASIL. Neurology 2016;86: 1964-1974.

25. Collongues N, Derache N, Blanc F, Labauge P, de Seze J, Defer G. Inflammatory-like presentation of CADASIL: a diagnostic challenge. BMC Neurol 2012;12:78.

26. Shiga A, Nozaki H, Yokoseki A, et al. Cerebral small-vessel disease protein HTRA1 controls the amount of TGF- $\beta 1$ via cleavage of proTGF- $\beta 1$. Hum Mol Genet 2011; 20:1800-1810.

27. Graham JR, Chamberland A, Lin Q et al. Serine protease HTRA1 antagonizes transforming growth factor- $\beta$ signaling by cleaving its receptors and loss of HTRA1 in vivo enhances bone formation. PLoS One 2013;8:e74094.

28. Tikka S, Baumann M, Siitonen M, et al. CADASIL and CARASIL: CADASIL and CARASIL. Brain Pathol 2014;24:525-544.

29. Zellner A, Scharrer E, Arzberger T, et al. CADASIL brain vessels show a HTRA1 lossof-function profile. Acta Neuropathol 2018;136:111-125.

30. Li MO, Wan YY, Sanjabi S, Robertson AKL, Flavell RA. Transforming growth factor- $\beta$ regulation of immune responses. Annu Rev Immunol 2006;24:99-146.

31. Chen J, Van Gulden S, McGuire TL, et al. BMP-responsive protease HtrAl is differentially expressed in astrocytes and regulates astrocytic development and injury response. J Neurosci 2018;38:3840-3857.

32. MacVicar BA, Newman EA. Astrocyte regulation of blood flow in the brain. Cold Spring Harb Perspect Biol 2015;7:a020388.

33. Olabarria M, Putilina M, Riemer EC, Goldman JE. Astrocyte pathology in Alexander disease causes a marked inflammatory environment. Acta Neuropathol 2015;130: 469-486.

34. Kondo T, Funayama M, Miyake M, et al. Modeling Alexander disease with patient iPSCs reveals cellular and molecular pathology of astrocytes. Acta Neuropathol Commun 2016;4:69.

35. Li L, Tian E, Chen X, et al. GFAP mutations in astrocytes impair oligodendrocyte progenitor proliferation and myelination in an hiPSC model of alexander disease. Cell Stem Cell 2018;23:239-251.e6. 


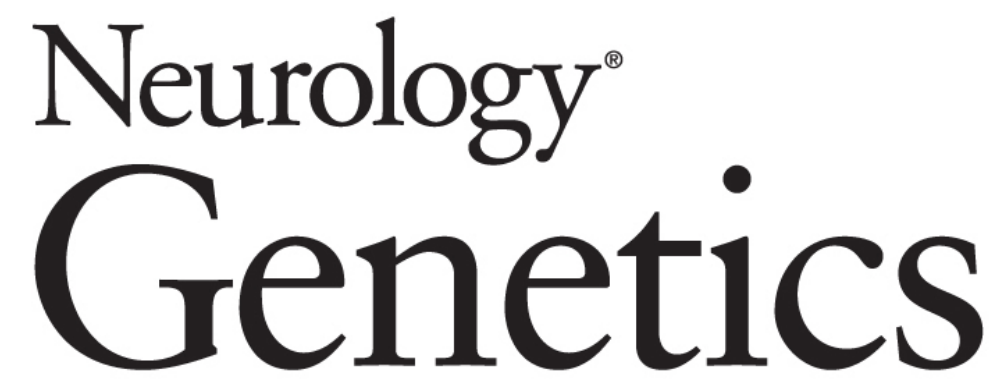

Novel mutation in HTRA1 in a family with diffuse white matter lesions and
inflammatory features

Amin Ziaei, Xiaohong Xu, Leila Dehghani, et al.

Neurol Genet 2019;5;

DOI 10.1212/NXG.0000000000000345

This information is current as of July 8, 2019

Neurol Genet is an official journal of the American Academy of Neurology. Published since April 2015, it is an open-access, online-only, continuous publication journal. Copyright Copyright () 2019 The Author(s).

Published by Wolters Kluwer Health, Inc. on behalf of the American Academy of Neurology.. All rights reserved. Online ISSN: 2376-7839.

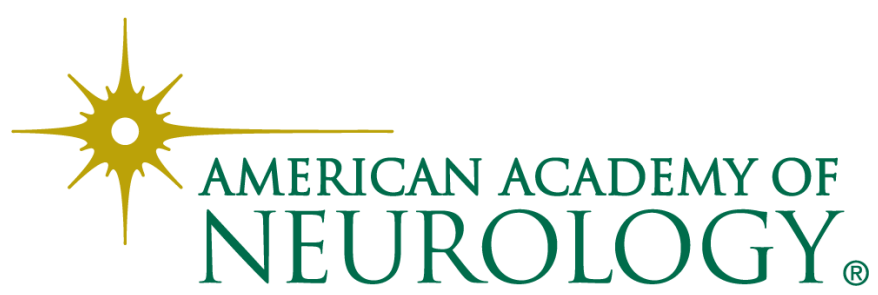




\section{Updated Information \& Services}

References

Subspecialty Collections

Permissions \& Licensing

\section{Reprints}

including high resolution figures, can be found at: http://ng.neurology.org/content/5/4/e345.full.html

This article cites 35 articles, 8 of which you can access for free at: http://ng.neurology.org/content/5/4/e345.full.html\#\#ref-list-1

This article, along with others on similar topics, appears in the following collection(s):

All Clinical Neurology

http://ng.neurology.org//cgi/collection/all_clinical_neurology

\section{All Genetics}

http://ng.neurology.org//cgi/collection/all_genetics

Genetic linkage

http://ng.neurology.org//cgi/collection/genetic_linkage

Stroke in young adults

http://ng.neurology.org//cgi/collection/stroke_in_young_adults

Vascular dementia

http://ng.neurology.org//cgi/collection/vascular_dementia

Information about reproducing this article in parts (figures,tables) or in its entirety can be found online at:

http://ng.neurology.org/misc/about.xhtml\#permissions

Information about ordering reprints can be found online:

http://ng.neurology.org/misc/addir.xhtml\#reprintsus

Neurol Genet is an official journal of the American Academy of Neurology. Published since April 2015, it is an open-access, online-only, continuous publication journal. Copyright Copyright $\odot 2019$ The Author(s). Published by Wolters Kluwer Health, Inc. on behalf of the American Academy of Neurology.. All rights reserved. Online ISSN: 2376-7839.

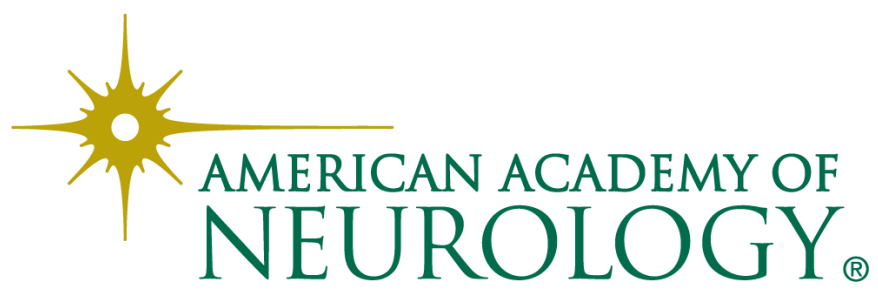

